\title{
Interelation of Qiyās Ushul Nahwi \& Qiyās Ushul Fiqh In Islamic Law Construction Framework
}

\section{Anwar Saleh Hasibuan*) and Ghofar Siddiq ${ }^{* *}$}

*) Student of Master of Law, Faculty of Law, Universitas Islam Sultan Agung (UNISSULA) and Teacher at the Al Madina Islamic School Foundation, Sampangan, Semarang, E-mail: anwarsaleh.hsb.86@gmail.com

${ }^{* *}$ Islamic Studies Faculty, Universitas Islam Sultan Agung (UNISSULA) Semarang

\begin{abstract}
.
Qiyās in the scope of Islamic scientific studies is not only studied and discussed in the study of Ushūl Fiqh science, but also in the study of Ushūl Nahwi science it is also studied and discussed about Qiyās. This article attempts to analyze, study and explain the form of interrelation that occurs between Qiyās Ushūl Nahwi and Qiyās Ushūl Fiqh in relation to Islamic legal constructs by describing the forms of the relationship between the similarities and differences between the two.
\end{abstract}

Keywords: Qiyās, Ushūl Nahwi, Ushūl Fiqh, Construction, Islamic Law

\section{Introduction}

Especially for those who are involved in the field of Islamic law, talking about Qiyās is of course familiar to the ears even in the realm of practice or application of Islamic law produced by this Qiyās. Most of the problems of Islamic law contained in fiqh literature are the result of Qiyās. Qiyās as agreed by scholars and all mażhabs is one of the sources of Islamic law. Unlike other ijtihad methods, Qiyās is a systematic process of reasoning to grasp legal provisions. He fully relies on authority, such as the Qur'an, Sunnah and Ijmā'. The discussion of Qiyās in the scope of Islamic scientific studies is not only studied and discussed in the study of Ushūl Fiqh science,

As a method of discovering and establishing Islamic law, Qiyās certainly does not escape criticism and rejection. As is well known that among those who reject and criticize Qiyās in the study of Ushūl Fiqh science is' Alī bin Ahmad bin Sa'īd bin Hazm bin Gālib bin Șālih bin Sufyān bin Yazīd or who is usually called Abū Muhammad, ${ }^{1}$ which in the Fiqh discourse he is often referred to by Fuqahā 'as Ibn Hazm az-Zāhirī. He is a Fiqh scholar, historian, writer, who comes from Andalusia as well as a critic who initially mentions Maliki, then moves mażhab to school of Shāfi'ì, and finally changes Zāhirī (literal mażhab). ${ }^{2}$ Criticism and rejection of Qiyās as a method of ijtihad is not limited to criticism and rejection without basis and argument. However, his criticism and rejection of the Qiyās uses the verses of the Qur'an and Hadiś as many scholars use them in stating the validity and authenticity

\footnotetext{
${ }^{1}$ Muhammad Ridwān ad-Dāyah. (2013). Silsilah A'lām Li an-Nāsyi'ah al-'Adad "19" Ibnu Hazm alQurțubī, Ed. I, Damaskus: Wizārah aś-Śaqāfah al-Hai'ah al-'Āmmah as-Sūriyyah Li al-Kitāb Mansyūrāt aț-Tifl. p. 23-24.

${ }^{2}$ Chamim Tohari, Argumentasi Ibn Hazm: Dekonstruksi Kehujjahan Qiyās Sebagai Metode Penetapan Hukum Islam, Istinbath Jurnal Hukum Vol. 13 No. 1 (2016) url: http://ejournal.metrouniv.ac.id/index.php/istinbath/article/view/540/470, p. 5-7.
} 
of the Qiyās. Among the examples from the verses of the al-Qur'ān which he uses in criticizing and rejecting Qiyās are those in surah Ali 'Imran verse 7. In his view, people who do takwil on mutasyābihāt verses are considered as people whose hearts tend to astray, slander and spread slander. He emphatically says that Qiyās are inherently inferior to Zan (conjecture), therefore he calls Qiyās a lie canceled by Naș (text) itself. He even strengthened his view by citing the verse of al-Qur'ān Surah an-Najm verse 28. Based on this verse, according to him, Zan (allegation) is considered a case that is not haq or which means vanity, while Zan (allegation) is stronger than Qiyās. So Qiyās in Ibn Hazm's view is the most vanity matter. Besides the verses mentioned above, there are many other verses that are used in criticizing, rejecting and undermining the validity and validity of the Qiyās. ${ }^{3}$

Apart from the verses of the Qur'an, Ibn Hazm also criticized and rejected the use of hadī-Hadīs used by supporters of Qiyās. Among the hadī used by supporters of Qiyās are Hadiśs regarding ijtihad, that is, if the ijtihad of a mujtahid is correct, then the reward is two, and if the ijtihad of a mujtahid is wrong then the reward is one. It seems that the supporters of Qiyās equate the meaning of ijtihad with $R a^{\prime} y u$ one meaning with Qiyās. Ibn Hazm and the Zahirì mazhab reject the interpretation proposed by the supporters of these Qiyās who are of the view that Qiyās is part of ijtihad. According to Ibn Hazm and the Zahirī school of thought, the Hadiś is not related to the Qiyās issue, so it should not be used to legalize Qiyās. Otherwise, The Hadiśs speaks of the virtue of ijtihad which is different from Qiyās. Because the meaning of ijtihad according to Ibn Hazm is to explore the laws of al-Qur'an and Hadīs, while Ra'yu is wisdom related to benefit. This is what the Hadiśs suggests. Instead of making laws in ways that hadī discouraged, such as doing Qiyās by equating the new problem law with the problem law in Naș (text). Such things according to Ibn Hazm and his mazhab, are strongly discouraged by the above Hadīś. Instead of making laws in ways that hadī discouraged, such as doing Qiyās by equating the new problem law with the problem law in Nas (text). Such things according to Ibn Hazm and his mazhab, are strongly discouraged by the above Hadiśs. Instead of making laws in ways that hadī discouraged, such as doing Qiyās by equating the new problem law with the problem law in Naș (text). Such things according to Ibn Hazm and his mazhab, are strongly discouraged by the above Hadiś. $^{4}$

In the other hand, in the study of Ushül Nahwi science, the discussion related to Qiyās is also not free from criticism and rejection. Among those who rejected the Qiyās was Ibn Maḍā al-Qurțubī a Nuhāt (Arabic syntactic expert) who came from Andalusia, who also said żahirī (literal mażhab). ${ }^{5}$ Qiyās according to Ibn Maḍa when used in language (nahwu science) is not a prohibited thing and he allows it. It's just that the Qiyās that are allowed are Qiyās which are accompanied by clear textual evidence. If no clear text is found, which can corroborate something that is being Qiyās, then this kind of Qiyās cannot be accepted and must even be rejected. Apart

\footnotetext{
3Ibid. p. 11-13.

4Ibid., P. 15-16.

Inayatur Rashidah, Ideology of Fiqh Schools and Social Politics in Nahwu Rule: Ibn Madha ar Radd ala al-Nuhat, Journal of Ulul Albab Vol. 12 No. 2 (2011), url:http://moraref.kemenag.go.id/documents/article/97406410605812664/download., p. 200.
} 
from that, Ibn Maḍā also rejected Qiyās Aqlī, the reason being that the principle of equating two things because the similarity of 'illat or cause (between the law of origin and the branch) is a weak principle. Because, the form of similarity (almusyabbahah) contained in the origin and branches is imperfect. As for another reason, that the Arabs did not necessarily and did not want what the Nuhāt did. ${ }^{6}$

From the two examples of criticism and rejection of Qiyās as described above, several questions can be asked including the following; whether the Qiyās Ushūl Nahwi and Qiyās Ushūl Fiqh have a relationship and are related to each other? Then do they also have a relationship and relationship with the construction of Islamic law? Then if both of them have a relationship and are related to each other, then what is the form of the relationship and the relationship between the two in the construction of Islamic law?

\section{Research Methods}

This research uses Comparative Law Approach. That the article attempts to analyze, study and explain the form of interrelation that occurs between Qiyās Ushūl Nahwi and Qiyās Ushūl Fiqh in relation to Islamic legal constructs by describing the forms of the relationship between the similarities and differences between the two.

\section{Result and Discussion}

\subsection{The Interrelation Between Ushūl Nahwi And Ushūl Fiqh}

As we already know that the existence of al-Qur'ān and al-Hadīș is incontrovertible evidence regarding the status and position of Arabic in Islamic law. This is because Arabic is the only language chosen by Allah and His Messenger to narrate rules, provisions, recommendations and inspirational stories in both. Starting from this basis, all Ushūl Fiqh scholars agree that Arabic is an absolute requirement that must be mastered by Islamic jurists. This means that a person does not meet the criteria as a mujtahid if he is not able to understand Arabic. The reason is very clear, the primary sources and references in the activity of extracting Islamic law are al-Qur'ān and al-Hadīs. So it is impossible for a mujtahid to be able to understand the two sources above let alone reveal the secrets in them if he does not know and does not understand Arabic. All of these Ushūl Fiqh scholars almost do not have different views on this matter. Namely, making knowledge of Arabic as one of the conditions that must be met by someone who wants to carry out activities to explore Islamic law (ijtihad). ${ }^{7}$ Exploring law in Islam, of course, must understand the sources of religious law, which in this case the source is generally divided into two, namely an-nuṣūs (texts) and gair an-nuṣūs

6Wati Susiawati, Ushul al-Nahwi Dalam Perspektif Ibn Madha, Arabi: Journal Of Arabic Studies Vol. 2 No. 2 (December 2017), url: http://journal.imla.or.id/index.php/arabi, p. 165-166.

7 Mohammad Hafid, 19 December 2019, Memperingati Hari Bahasa Arab Dunia, Ini Urgensi Bahasa Arab Dalam Memahami Hukum Islam, https://bincangsyariah.com/kalam/bahasa-arab/, accessed on 04 October 2020. 
(besides texts). As for an-nushus, namely al-Qur'ān and the Sunnah of the Prophet Muhammad and gair an-nushus itself such as Qiyās, Ijmā ', Istișhāb and so on. ${ }^{8}$

Nahwu science is a scientific discipline that aims to understand Arabic texts. Apart from these goals, the science of nahwu also has the aim of protecting the Qur'an from mistakes (lahn). ${ }^{9}$ Various cases of lahn and differences in qirā'āt (readings) are the main factors that encourage ideas and ideas to standardize the rules of Arabic language or grammar (nahwu). The formulation of rules that have been carried out by the scholars since the first century of Hijriyyah to pass through several phases, basically in terms of quality and essence of the material has talked about the substance of Ushūl Nahwi.10

If you can compare it to brother and sister, Ushūl Nahwi is the younger brother of Ushül Fiqh. Why is that? Because if we trace the history of the birth of the two sciences in Arabic literature, we will find that the science of Ushül Fiqh was born before the birth of the science of Ushūl Nahwi. ${ }^{11}$ Muhammad Ismā'îl alMasyhadanī in his book al-Ijmā 'Fì Ushūl an-Nahwi al-'Arabī, stated that the science of Ushūl Fiqh and science of Hadiss had been codified first, then followed by the codification of Nahwu science (Arabic syntax). He added that since the middle of the second century hijriyyah the scholars had written syar'i sciences such as hadīs and compiled (recorded) the science of Fiqh and the science of Tafsìr.

$8 \mathrm{Nu}$ Sudan, 02 October 2019, Urgensi Bahasa Arab Dalam Islam, https://pcinusudan.com/2019/10/urgensi-bahasa-arab-dalam-islam/, accessed on 04 October 2020.

${ }^{9}$ Rini, Ushul al-Nahwi al-Arabi: Kajian Tentang Landasan Ilmu Nahwu, Arabiyatuna Jurnal Vol. 3 No. 1 Mei (2019), url: http://journal.iaincurup.ac.id/index.php/ARABIYATUNA/article/view/773/pdf, p. 146.

${ }^{10}$ Ahmad Zaky, Ushūl Nahwi Sejarah dan Perkembangannya, Jurnal Waraqat Vol. IV No. 1 JanuaryJune (2019), url: https://www.assunnah.ac.id/journal/index.php/WRQ/article/download/69/59/+\&cd=33\&hl=id\& ct=clnk\&gl=id, p. 17.

11 The jumhūr ulama or most of the ulama both salaf and khalaf have agreed that the actual beginning of the codification in ushūl fiqh was initiated by imam Muhammad bin Idrīs asy-Syāfi'ì rahīmahullāh or better known as imam asy-Syāfi'ī in his book entitled ar-Risālah. Ar-Risālah is a book of ushūl fiqh written at the end of the second century AH. Ar-Risālah is in the form of a letter sent to the imam 'Abdurrahmān bin Mahdī bin al-Lu'lu'ī (w $198 \mathrm{H}$ ). and the book is the book of ushūl fiqh that first came to us. However, on the other hand, some argue that Abū Hanifah and his two companions, Abū Yusūf and Muhammad bin al-Hasan asy-Syaibāni were the first to speak and write about ushūl fiqh, then followed by Imam asy-Syāfi'î. Among those who say that it is Abū alWafā 'al-Afgānī in the preface or preface of the book ushūl as-Sarkhasī which is tahqīq- (verified) by him. In the preface he states that:

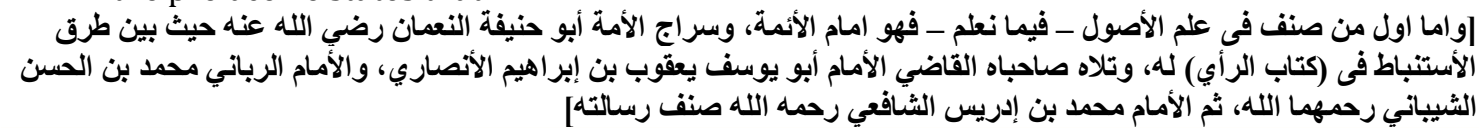

"And as for the first person to compose (write) in the science of ushūl fiqh - as we know - he is the imam of the imams and enlightenment of the ummah Abū Hanifah an-Nu'mān radiyyallahu 'anhu, where he explains about the methods istinbat in his book "ar-Ra'yu". And followed by his two companions, namely al-Qāḍī al-Imām Abū Yūsuf Ya'qūb bin Ibrāhīm al-Anșārī and al-Imām arRabbānī Muhammad bin al-Hasan asy-Syaibānī rahīmahumallāh, then al-Imām Muhammad bin Idrīs asy-Syāfi ' ì rahīmahullāh composes (writes) the risālah. " Look at Ahmad 'Abdul Bāsiṭ Hāmid, 2014, Min Qadaya Ushūl Nahwi 'Inda 'Ulamā' Ushūl al-Fiqh, ed.I, Wizārah al-Auqāf Wa asy-Syu'ūn alIslamiyyah, Kuwait, p. 27. 
Furthermore, these scholars turned to writing and codifying sciences that were not syar'ī such as linguistics and nahwu science (Arabic syntax). ${ }^{12}$

Ushūl Nahwican be said to be the foundation or foundation for Arabic grammar. Its position towards nahwu is the same as that of Ushūl Fiqh towards Fiqih. ${ }^{13}$ Like Ushūl Fiqh, Ushūl Nahwi are the principles that underlie the science of nahwu in its various problems and applications. Ushūl Nahwi not only focuses on the sources, arguments and principles of the formulation of nahwu science as a science, but also examines various differences of opinion among the nuhäts (Arabic syntactic experts) in understanding the phenomena of the Arabic language from the time of jahiliyyah to the standardization and bookkeeping or codification of nahwu. ${ }^{14}$ Ushūl Nahwi is a science that discusses al-adillah an-nahwiyyah (dalil-dalil nahwu or legal sources in nahwu), the procedures for issuing the nahwu rules, and their application. As for what is meant by al-adillah an-nahwiyyah (arguments for nahwu) here are as-Simā ', al-Ijmā', al-Qiyās and al-Istișhāb. ${ }^{15}$

Abū al-Barakāt 'Abdurrahmān bin Muhammad Al-Anbārī (w 577 H) or better known as al-Anbārī, in his book' Luma 'al-Adillah Fī Ushūl Nahwi, which is further quoted by Ahmad' Abdul Bāsit Hāmid in his book Min Qadaya Ushūl Nahwi 'Inda' Ulamā 'Ushūl al-Fiqh, states that Ushūl Nahwi is: ${ }^{16}$

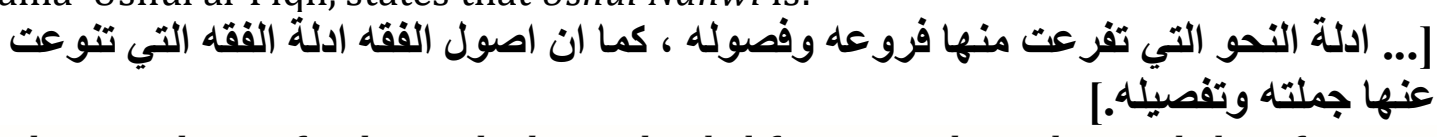

"... the postulates of nahwu which are divided from it its branches and classifications (articles), just as Ushūl Fiqh is a variety of fiqh arguments or types of sentences and details."

'Abdurrahmān Jalāluddīn as-Suyūțī (w $911 \mathrm{H}$ ) in his book al-Iqtirāh Fī' Ilmi Ushūl an-Nahwi, detailing the definition related to the Ushūl Nahwi by writing that: 17

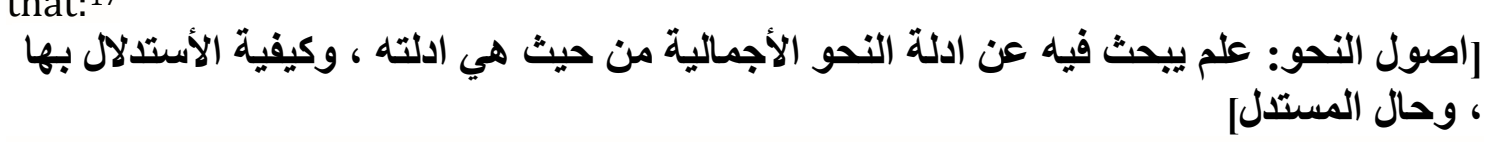

"Ushūl Nahwi is a science that studies in it the nahwu arguments globally (in general) in terms of it as their arguments, and the method of deducing the arguments with it, as well as the condition of the person who uses the argument (mustadil/mustanbit)."

The two definitions of Ushūl Nahwi above, if we combine them with the definitions in Ushul Fiqh, then we will find similarities or similarities in definitions. This is because the Ushül Nahwi scholars have been inspired by the scientific discourse developed by the Ushül Fiqh scholars, so that the Ushūl Nahwi scholars adopted the definition contained in Ushül Fiqh and put it into the definition of Ushūl Nahwi. Not only that, almost all of the discussion chapters in the Ushül Fiqh

\footnotetext{
${ }^{12}$ Muhammad Ismā'il al-Masyhadānī. (2013) al-Ijmā' Dirāsah Fī Ushūl an-Nahwi al-'Arabī, Ed. I, Oman: Dār Gidā'. p. 22-23.

${ }^{13}$ Look at Rini, loc. cit.

${ }^{14}$ Look at Ahmad Zaky, loc. cit.

${ }^{15}$ Ibid, p. 30.

${ }^{16}$ Look at Ahmad 'Abdul Bāsit Hāmid, op. cit., p. 23.

17 Ibid.
} 
were also adopted into the discussion chapters in the Ushūl Nahwi. As for the definition of Ushül Fiqh as written in the science of Ushūl Fiqh, namely: ${ }^{18}$

$$
\text { [اصول الفقه هو: البحث في ادلة الفقه الأجمالية ، وكيفية الأستدلال بها ، وحال المستدل] }
$$

"Ushul fiqh is a science that studies the arguments of fiqh globally (general), and the method of concluding the arguments with it, as well as the condition of the person who uses these arguments (mustadil/mustanbit)."

From the combination of the two definitions of Ushūl Nahwi and Ushūl Fiqh as explained above, it provides an indication that the two sciences have a relationship between one another. On the other hand, although the two sciences, namely the science of Ushul Nahwi and science of Ushül Fiqh, have different scientific scopes, both of them have a very strong relationship, in fact both of them influence each other. According to Ibn Jinnī, as quoted by Ahmad Zaky, he explained that the influence of Ushül Fiqh on Ushül Nahwi was very clear. At least it can be seen from the relationship between 'illat nahwu and' illat fiqh. Ahmad Zaky also quoted what Mahmūd Ahmad Nihlah had stated, who said that the science of Ushūl Fiqh was the science that had the most influence on the study of nahwu compared to other sciences. Evidence of this influence, namely: 19

- Opening the inspiration and thorough attention to the Naș which is used as a source (an-nusuus) which is then very useful to criticize the text, both in terms of sanad and eyes which are then used as istisyhād.

- In the discourse of Ushūl Fiqh, the principle of Ushūl Fiqh is known with the concept of al-Maslahah (المصلحة) which is formulated with the sentence lā darara wa lā dirāra (لاضرر ولا ضرار), while in the discourse Ushūl Nahwi is known in the Ushūl Nahwi rule with the concept of al-fā'idah (الفائدة) which is then formulated in the sentence lā khața'a wa lā lubsa (لاخطأ ولا لبس).

\subsection{The form of interrelation between Qiyās Ushūl Nahwī and Qiyās Ushūl Fiqh}

As explained at the beginning of this article, the use of the term Qiyās is not only used in the study of Ushūl Fiqh, but has also been used in the study of Ushül Nahwi science. In the study of the science of Ushūl Fiqh, Qiyās ranks fourth from sources or legal propositions, namely: al-Qur'ān, Sunnah (al-Hadīs), Ijmā' and Qiyās, while in the study of Ushūl Nahwi Qiyās sometimes ranks second, if al-Ijmā 'is not used, so that the postulates of the Nahwu law become: as-Simā ', al-al-Qiyās and al-Istișhāb. ${ }^{20}$ Sometimes it also ranks third if you add al-Ijmā, so that there are four arguments for the Nahwu law, namely: as-Simā ', al-Ijmā ', al-al-Qiyās and alIstișhāb. ${ }^{21}$

\footnotetext{
18 Jamāluddīn Abī Muhammad 'Abdurrahīm bin al-Hasan al-Isnawī. (2011). al-Kaukab ad-Durrī Fī Kaifiyyāt Takhrīj al-Furū' al-Fiqhiyyah 'Alā al-Masā'il an-Nahwiyyah, ed. by. 'Abdurrazzāq 'Abdurrahmān as-Sa'dī, Ed. II, Cairo: Dār al-Anbār, Dār Sa'ad ad-Dīn, p. 29-30. ${ }^{19}$ Look at Ahmad Zaky, op. cit. p. 27-28.

${ }^{20}$ Nana Jumhana, Metode Qiyās Sebagai Landasan Epistemologi Nahwu (Studi Tentang Metode Qiyās dan Kedudukannya dalam Taq'îd an-Nahwi), Al Qalam Jurnal Kajian Keislaman, Vol. 31 No. 2 JuliDecember (2014), url: http://jurnal.uinbanten.ac.id/index.php/alqalam/article/view/565, p. 215. 21 This is because according to Ibn Jinnī there are three arguments for Nahwu, namely: as-Simā ', alIjmā' and al-Qiyās. As for al-Anbāri, it is different from Ibn Jinnī, he said that there are three
} 
The form of interrelation or reciprocal relationship that occurs between Qiyās Ushūl Nahwī and Qiyās Ushūl Fiqh in general begins from the history of the compilation and bookkeeping of Ushül Nahwi itself. This is as previously explained, that the Ushül Nahwi scholars were inspired by the scientific discourses developed by the Ushül Fiqh scholars, so that the Ushūl Nahwi scholars followed the steps and methods used by the Ushül Fiqh scholars in establishing and compiling as well as codifying the Ushūl Nahwi. ${ }^{22}$

Apart from adopting the definition of Ushūl Fiqh in general, the Ushūl Nahwi scholars also adopted the definition of Qiyās in particular. So that when we read the literature about Qiyās contained in Ushūl Nahwi, we will find that by definition they also almost have similarities and similarities with the definition of Qiyās in Ushūl Nahwi. According to the term Ushūl Fiqh, as quoted by İman 'Umar Muhammad Jādullāh and Faḍlullāh an-Nūr' Alī in a journal entitled al-Qiyās Baina Ushūl an-Nahwi Wa Ushūl al-Fiqh, that Qiyās is linking a matter that has no Naș ( text) with other cases that have Nas (text) because between the two cases there is a similarity in their 'illat Hukum. ${ }^{23}$ As according to the term Ushül Nahwi as stated by al-Anbārī, Qiyās is an analogy of branch law by using the original law. Another definition states that Qiyās is the analogy of the branch law against the original law with a certain 'god. Or Qiyās is submitting the branch law to the original law because of the jāmi '(equality)' illah between the two. The three definitions according to al-Anbārī have closeness and the same meaning. ${ }^{24}$

According to Tammām Hassān, Qiyās in the view of the nuhāt are categorized into two kinds of Qiyās, namely the first is al-Qiyās al-Isti'mālī, which means applied Qiyās (application/practice), while the second is al-Qiyās an-Nahwi, which means Qiyās relating to nahwu law (theory). Regarding the two Qiyās, Tammām Hassān also gave an additional explanation that what is meant by al-Qiyās alIsti'mālī here is intihā 'kalam al-'arab, which is an effort to follow the words of the Arabs, while al-Qiyās an-Nahwi means haml gair. al-manqūl ilā al-manqūl iżā kāna fī ma'nāhu which means accompanying or carrying or analogizing non-manqūl (which is not narrated) to manqūl (narrated) if they have the same meaning. ${ }^{25}$

Apart from similarities or similarities in terms of definition, the two Qiyass contained in Ushūl Nahwi and Ushūl Fiqh also have the same or similar pillars, which consist of four pillars, namely: al-așl (الأصل), al-Far'u (الفرع), Hukm al-al-aṣl (الأصل) Etymologically, it is lafaz musytarak which can be interpreted as a principle, basis, source, and base. Meanwhile what is meant by al-așl (الأصل) in the discussion of Qiyās Ushūl Fiqh are old cases which are used as objects of likeness or cases where there is already textual legal stipulation

arguments of nahwu, namely: Naql, Qiyās and Istișhābul hāl. Likewise the level (level) and the conclusions of his arguments. Al-Anbārī had added Istiṣhābul hāl and did not mention Ijmā '. As if al-Anbarī did not see it as taking evidence (argument) in Arabic. Meanwhile, as-Suyūṭi stated that there are 4 of the nahwu's arguments, namely: as-Simā', al-Ijmā' dan al-Qiyās dan Istiṣhābul hāl.

${ }^{22}$ Look at Ahmad 'Abdul Bāsit Hāmid, op. cit., p. 65-66.

23 Iman 'Umar Muhammad Jādullāh dan Faḍlullāh an-Nūr 'Alī, al-Qiyās Baina Ushūl an-Nahwi Wa

Ushūl al-Fiqh, SUST Journal Of Humanities, Vol. 16 No. 5 (2015), url: http://repository.sustech.edu/handle/123456789/18122, p. 64.

${ }^{24}$ Look at Nana Jumhana, op.cit., p. 216.

25 Ibid. 
in both Naș and ijmā '.26 As for the meaning of al-aṣl (الأصل) in the discussion of Qiyās Ushūl Nahwi, namely texts quoted or quoted from the Arabs which can be used as evidence or arguments, both excerpts (quotes) through simā'an (heard), through riwayāt, orally, or through notes which is used as a guide in nahwu law. Emìl Badī 'Ya'kūb quoted the words of Ibn Jinnì who said that the words of the Arabs can be viewed from a stable point of view or not the use or application of Qiyās to them, this can be seen from four kinds of circumstances as follows: ${ }^{27}$

- Regulate on Qiyās and its application, such as the sentence: qāma zaidun (قام زيدّ) which means zaid has stood, darabtu zaidan (ضَربتُ زَيْيًَا) which means I've hit Zaid, marartu bi zaidin (مررت بزياٍٍ) which means I've been walking with Zaid.

- Be regular in the Qiyās, and Sha (defective/irregular) in its application, such as the application of fi'il mā muḍārī '(ف⿴囗大) or present and future verbs, such as these two words: yażaru (ذ) and yada'u (يد).

- Regular in the application, and shāż (defective/irregular) in the Qiyās, such as

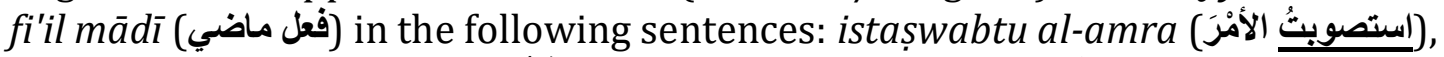

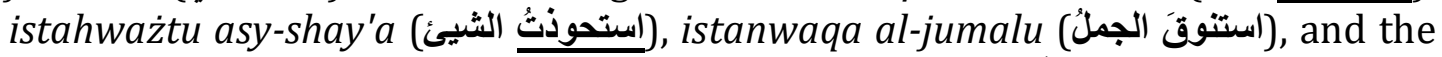
shāż (defective/irregular) Qiyās in all fi'il māọī (فعل ماضي) is by: qalb al-wāwi alifan (فعل ماضي) or change and replace the wawu letter into the alif.

- Shāż (defective/irregular) on Qiyās and its application as a whole, such as the

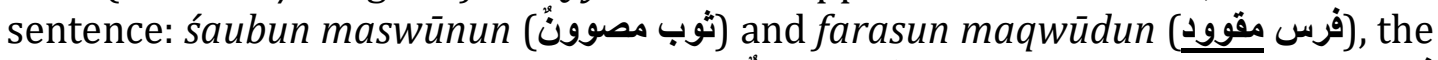

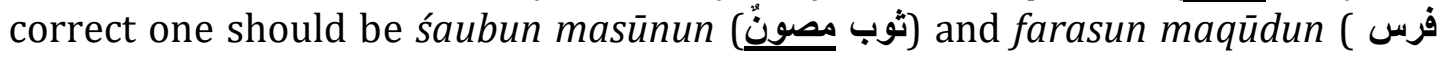
مقود).

For example or examples of the same method, we can also see the use of all the pillars of Qiyās that are in the Ushul Nahwi. For example, such as determining the law of $n \bar{a}^{\prime} i b$ al-fä'il which is Qiyāskan against $f \bar{a} ' i l ;{ }^{28}$

- $A l-A l$, every fä'il is read rafa '(dammah)

- Al-Far'u, nā'ib al-fā'il pronounced rafa '(dammah)

- Al-Hukm, nā'ib al-fā'il should be read rafa '(dammah)

- Al-'Illah, because both of them are musnad ilaih.

Other similarities can also be seen in the use of the terms' illah such as al'illah al-muta'addiyah, al-'illah al-mu'aśśirah, al-'illah gair al-muta'addiyah, al-'illah gair. al-mu'aśśirah, al-'illah al-qașīrah, al-'illah al-wāqifah gair al-jāriyah, al-'illah al-muwajjahah, and al-'illah al-muwajjabah. And so on. ${ }^{29}$ Thus it can be said that between Qiyās Ushūl Nahwi and Qiyās Ushūl Fiqh have a very strong bond and influence each other in the framework of the construction of Islamic legal buildings.

\footnotetext{
${ }^{26}$ Look at Ahmad Masfuful Fuad, Qiyas Sebagai Salah Satu Metode Istinbāṭ Al-Hukm, Mazahib Jurnal Pemikiran Hukum Islam, Vol. XV, No. 1 (June 2016), url: https://journal.iainsamarinda.ac.id/index.php/mazahib/article/view/606/447, p. 46.

${ }^{27}$ Hairudin, Akar Historis Ilmu Nahwu, Al Mahara Jurnal Pendidikan Bahasa Arab, Vol. 5, No. 1 (June 2019), url: http://ejournal.uin-suka.ac.id/tarbiyah/index.php/almahara/article/view/2418/1636, p. 24.

${ }^{28}$ Look at Ahmad Zaky, op. cit. p. 25.

${ }^{29}$ Ibid, p. 27.
} 


\section{Conclusion}

The number of conclusions that Ushūl Nahwi is an underlying basis for establishing the laws of nahwu, while Ushül Fiqh is the basis for establishing fiqh. Both of these disciplines have an influence on one another in terms of determining Islamic law. The Qiyās method contained in the Ushūl Nahwi is influenced by the Qiyās method in fiqh, both in terms of definition, pillars, terminology 'illat and others. Wallāhu A'lam Bișșawāb.

\section{References}

Journals:

[1] Ahmad 'Abdul Bāsiṭ Hāmid, 2014, Min Qadaya Ushūl Nahwi 'Inda 'Ulamā' Ushūl al-Fiqh, ed.I, Wizārah al-Auqāf Wa asy-Syu'ūn al-Islamiyyah, Kuwait

[2] Ahmad Masfuful Fuad, Qiyas Sebagai Salah Satu Metode Istinbāt Al-Hukm, Mazahib Jurnal Pemikiran Hukum Islam, Vol. XV, No. 1 (June 2016), url: https://journal.iainsamarinda.ac.id/index.php/mazahib/article/view/606/447

[3] Ahmad Zaky, Ushūl Nahwi Sejarah dan Perkembangannya, Jurnal Waraqat Vol. IV No. 1 January-June (2019), url: https://www.assunnah.ac.id/journal/index.php/WRQ/article/download/69 $\angle 59 /+\& c d=33 \& h \mathrm{l}=\mathrm{id} \& \mathrm{ct}=\mathrm{clnk} \& \mathrm{gl}=\mathrm{id}$

[4] Chamim Tohari, Argumentasi Ibn Hazm: Dekonstruksi Kehujjahan Qiyās Sebagai Metode Penetapan Hukum Islam, Istinbath Jurnal Hukum Vol. 13 No. 1 (2016) url: http://ejournal.metrouniv.ac.id/index.php/istinbath/article/view/540/470

[5] Hairudin, Akar Historis Ilmu Nahwu, Al Mahara Jurnal Pendidikan Bahasa Arab, Vol. 5, No. 1 (June 2019), url: http://ejournal.uinsuka.ac.id/tarbiyah/index.php/almahara/article/view/2418/1636

[6] Iman 'Umar Muhammad Jādullāh dan Faḍlullāh an-Nūr 'Alī, al-Qiyās Baina Ushūl an-Nahwi Wa Ushūl al-Fiqh, SUST Journal Of Humanities, Vol. 16 No. 5 (2015), url: http://repository.sustech.edu/handle/123456789/18122

[7] Inayatur Rashidah, Ideology of Fiqh Schools and Social Politics in Nahwu Rule: Ibn Madha ar Radd ala al-Nuhat, Journal of Ulul Albab Vol. 12 No. 2 (2011), url:http://moraref.kemenag.go.id/documents/article/97406410605812664 Ldownload

[8] Nana Jumhana, Metode Qiyās Sebagai Landasan Epistemologi Nahwu (Studi Tentang Metode Qiyās dan Kedudukannya dalam Taq'îd an-Nahwi), Al Qalam Jurnal Kajian Keislaman, Vol. 31 No. 2 Juli-December (2014), url: http://jurnal.uinbanten.ac.id/index.php/alqalam/article/view/565, p. 215.

[9] Rini, Ushul al-Nahwi al-Arabi: Kajian Tentang Landasan Ilmu Nahwu, Arabiyatuna Jurnal Vol. 3 No. 1 Mei (2019), url: http://journal.iaincurup.ac.id/index.php/ARABIYATUNA/article/view/773/ pdf 
[10] Wati Susiawati, Ushul al-Nahwi Dalam Perspektif Ibn Madha, Arabi: Journal of Arabic Studies Vol. 2 No. 2 (December 2017), url: http://journal.imla.or.id/index.php/arabi

Books:

[1] Jamāluddīn Abī Muhammad 'Abdurrahīm bin al-Hasan al-Isnawī. (2011). alKaukab ad-Durrī Fì Kaifiyyāt Takhrīj al-Furū' al-Fiqhiyyah 'Alā al-Masā'il anNahwiyyah, ed. by. 'Abdurrazzāq ‘Abdurrahmān as-Sa'dī, Ed. II, Cairo: Dār alAnbār, Dār Sa'ad ad-Dīn

[2] Muhammad Ismā’il al-Masyhadānī. (2013) al-Ijmā̄' Dirāsah Fī Ushūl an-Nahwi al-'Arabī, Ed. I, Oman: Dār Gidā'

[3] Muhammad Ridwān ad-Dāyah. (2013). Silsilah A'lām Li an-Nāsyi'ah al-'Adad "19" Ibnu Hazm al-Qurțubī, Ed. I, Damaskus: Wizārah aś-Śaqāfah al-Hai'ah al'Āmmah as-Sūriyyah Li al-Kitāb Mansyūrāt aț-Ṭifl

Internet:

[1] $\mathrm{Nu}$ Sudan, 02 October 2019, Urgensi Bahasa Arab Dalam Islam, https://pcinusudan.com/2019/10/urgensi-bahasa-arab-dalam-islam/, accessed on 04 October 2020.

[2] Mohammad Hafid, 19 December 2019, Memperingati Hari Bahasa Arab Dunia, Ini Urgensi Bahasa Arab Dalam Memahami Hukum Islam, https://bincangsyariah.com/kalam/bahasa-arab/, accessed on 04 October 2020 